\title{
ECONOMIC THEORIES OF CITIZENSHIP ASCENSION
}

AQ: The name of the author here

mismatches with

the name in the Contents and in List of Contributors. Please confirm the correct name.

\section{DON J. DEVORETZ}

AND NAHIKARI IRASTORZA

\begin{tabular}{lc}
\hline Introduction & 200 \\
Economic Theory of Clubs and Citizenship Ascension & 202 \\
Human Capital Theory of the Economic Impact of Citizenship & \\
$\quad$ Ascension & 204 \\
Comparative Empirical Evidence from Europe and North & \\
$\quad$ America under the Human Capital Model of Citizenship & \\
$\quad$ Ascension & 207 \\
Some Conclusions & 216 \\
\hline
\end{tabular}

\section{INTRODUCTION}

THE economic analysis of the acquisition and impact of citizenship ascension in its modern form circa 2000 onwards is limited to a complex, heterogeneous model that includes ascending immigrants' human capital endowments. Empirical studies based on this model lead us to conclude that there is an economic premium derived when immigrants acquire citizenship in their destination countries. However naïve economic models that focus on labour market outcomes have left these premiums 
undetected in the past (see, example.g., the classic work by Becker in the US). ${ }^{1}$ This purported lack of economic premiums from citizenship ascension left the economic analysis of citizenship ascension dormant until the early twenty-first century.

Even today, scholars in different countries arrive at varying conclusions on the causes and magnitude of this premium. Moreover, while the majority of these studies focus on the citizenship effects for immigrants, there are two important gaps in the literature: the effect of citizenship acquisition on others in the destination country and on residents in their origin countries.

Beyond the general question of the existence of an economic citizenship premium lies a host of more specific questions that must be addressed with a modern economic ascension model. First, how and why does the economic citizenship premium vary by gender, immigrant source country, immigrant entry class, and waiting period for citizenship ascension? The answers have important host country policy implications since addressing the influx of immigrants and time to ascension will allow the host country to maximize the derived economic benefits of citizenship ascension.

Another major question to address with an economic model of ascension is who are the economic winners or losers in the ascension process? Do host country residents economically gain or lose when a newly ascended immigrant appears? Moreover, what are the tax implications in the host country from citizenship ascension? Do new citizens pay more in taxes than they use in services, implying a net gain to existing residents? Both the average citizenship age and remaining lifetime income will influence the answer and a life cycle economic model of citizenship ascension will be needed to aid in the tax analysis. In a wider sphere, we must ask if the immigrant sending country is negatively or positively affected, economically, by citizenship ascension in the host country. Does the presence or absence of dual citizenship provisions in both the sending and host countries affect the size of the positive economic contributions for the sending countries after citizenship ascension in the host country?

Any economic model of citizenship ascension must be able to measure the impacts of existing immigrant and citizenship selection policies in a precise manner to decompose the source of the generally observed economic gain from citizenship ascension. The immigrant sending country and immigrant human capital selection criteria, along with a knowledge of the optimal waiting period for ascension, will allow the host country to absorb new citizens at no cost or maximize the benefit to the resident population depending on the host country's goal. This policy-oriented analysis of the economic impact of citizenship ascension expands on the 'club theory' model, which suggested that the admission of immigrants into the 'citizenship club' was predicated on existing club members gaining from new citizens' ascension. Without denying this general principle, the more modern economic model of citizenship ascension allows

${ }^{1}$ Gary Becker, The Economics of Discrimination (Chicago: University of Chicago Press, 1973). 
both an analysis of the sources of any premium and provides policy instruments to increase the size of these economic benefits to existing club members.

A summary question thus emerges: what modern economic theory of citizenship ascension provides a tool to answer the questions posed above? An endogenous human capital model involving citizenship ascension is the only extant economic theory to analyse and provide answers for a variety of immigrants across source countries with different levels of human capital. Such a model recognizes that the accumulation of various forms of human capital needed for citizenship ascension and the resulting economic premium from citizenship ascension lead to a select group of citizenship candidates.

The rest of this chapter is organized as follows: first, we present earlier economic approaches to citizenship ascension based on the club goods theory and we discuss their limitations. In the next section, we further develop the human capital theory of the economic impact of citizenship ascension introduced above. We then discuss the economic costs and benefits of citizenship acquisition for immigrants, origin and destination countries, and we illustrate these ideas with empirical examples from Europe and North America. The last section presents our conclusions.

\section{Economic Theory of Clubs And Citizenship Ascension}

In his book Citizenship and Immigration, Christian Joppke refers to Straubhaar in order to compare state membership (i.e. citizenship) to club membership. ${ }^{2}$ One of the points of comparison concerns the economic aspect of citizenship. In a world of migration, where an increasing number of people choose their states, these states become instrumental associations with robust admission policies. According to these policies, for existing members, the benefits of accepting new members must be higher than the costs implied in this decision. He cites two 'legitimate' admission criteria: the willingness to accept the club rules and the new members' ability to pay.

These state and club membership concepts point us to the further impacts of naturalization on the state as outlined by Tiebout and Buchanan. ${ }^{3}$ In Tiebout's attempt to build a satisfactory theory of public finance, one of the assumptions he makes is that there is an optimal community size for every public service provided by the

${ }^{2}$ Christian Joppke, Citizenship and Immigration (Cambridge: Polity Press, 2010).

${ }^{3}$ James M. Buchanan, 'An Economic Theory of Clubs', Economica 32, no. 125 (1965): pp. 1-14; Charles M. Tiebout, 'A Pure Theory of Local Expenditures', Journal of Political Economy 64, no. 5 (1956): pp. $416-424$. 
state to the members of such a community. This optimum, which implies that public goods are limited, is defined by the number of residents for which such services can be produced at the lowest average cost.

Likewise, according to Buchanan's economic theory of clubs, there is an optimal membership for almost any public or private activity people may engage in. The central question, according to him, is to determine the membership margin or the size of the most desirable cost and consumption sharing arrangement. As stated by Samuelson, unlike in the case of purely private goods, consumption of public goods by any one individual implies equal consumption by all others. ${ }^{4}$ However, the utility that each member receives from the consumption of any public or private good or service depends on the number of individuals who share their benefits, i.e. the size of the club. Full equilibrium in club size will be reached when the marginal benefits and costs of having a new member for any existing member are equal.

While Tiebout and Buchanan's ideas have inspired many scholars, they have also been contested by a few. In his proposal for a new concept of citizenship, which he names 'Citizenship: Organizational and Marginal', Frey refers to Buchanan's theory of clubs in the sense that (i) non-members can be excluded and (ii) the consumption among the citizens has public good characteristics. ${ }^{5}$ However, he argues that while Buchanan's analysis focuses on the benefits and costs of adding a member, the special relationship between the members and their club based on intrinsic motivations such as trust and loyalty is neglected.

Ruhs and Martin also address the question of the optimal community size by exploring the relationship between migrant numbers and rights. ${ }^{6}$ In this case, however, this optimal relationship refers to migrants' rights rather than to the benefits and costs for the host community. These authors claim that there is an inverse relationship between the number and rights of migrants employed in low-skilled jobs in high-income countries. This is generated by (i) the increased labour costs associated with more employment rights for workers, from the employers' perspective and (ii) the desire of governments in destination countries to minimize the fiscal costs of low-skilled immigration, by keeping migrant numbers low or by restricting their access to welfare. These immigrants' rights, as described by Ruhs and Martin, could be extended to include their right to apply for citizenship in the host country and the host country's rules for naturalization. For example, countries could discourage lowskilled immigrant residents from applying for citizenship-and therefore, favour the highly skilled ones-by setting restrictive conditions such as a high application fee, a high language proficiency requirement, or a challenging citizenship test.

\footnotetext{
${ }^{4}$ Paul A. Samuelson, 'The Pure Theory of Public Expenditures', Review of Economics and Statistics 36, no. 4 (1954): pp. 387-389.

${ }^{5}$ Bruno Frey, 'Flexible Citizenship for a Global Society', Politics, Philosophy \& Economics 2, no. 1 (2003): pp. 93-114.

${ }^{6}$ Martin Ruhs and Philip Martin, 'Numbers vs. Rights: Trade-Offs and Guest Worker Programs', International Migration Review 42, no. 1 (2008): pp. 249-265.
} 
If we apply the ideas above to the study of the economic aspects of citizenship, we could state that: (i) even if all immigrant residents are allowed to apply for naturalization if they meet the conditions to do so, host countries have some mechanisms to restrict the number of successful applications from less profitable immigrant groups such as low-skilled immigrants, refugees, and family migrants; and (ii) granting citizenship will be economically sustainable and even profitable for countries and their long-term members or citizens if the benefits of such action equal or surpass the costs involved. Costs include not only the initial legal-administrative process costs associated with admitting new citizens, but also the relationship between the consumption of public goods and the total taxable income generated by immigrants after they become citizens. To establish whether this correlation is positive or negative, a comparison should be made between the new citizen's public expenditure and revenue profiles in their pre-ascension versus post-ascension periods.

The discussion about numbers and rights is also relevant to assess the economic implications, for host countries, of granting citizenship to migrants. The costs and benefits of accepting new citizens vary among destination countries depending on a number of factors including: (i) the cost of the administrative process of citizenship ascension and who pays for them; (ii) the cost of the services provided by the state to their citizens versus the permanent residents in the host country; (iii) the tax revenue collected by the state from their citizens versus their permanent residents; and (iv) the economic premium of citizenship for new citizens versus permanent residents and its tax implications for the state. However, citizenship does not only have economic implications for the countries that grant it, but also for the new citizens themselves and for their countries of origin, as we will see in the next section.

In sum, the theory of clubs as applied to the economics of citizenship provides a quasi-economic theoretical framework to address this topic but, by being too general, it lacks the precision to measure the economic impacts of citizenship ascension for a diversity of potential citizen candidates over time. Such an approach is better provided by human capital theory, which we develop in the next section.

\section{Human Capital Theory of THE ECONOMIC IMPACT of Citizenship Ascension}

Evidence for an economic impact of citizenship ascension, finding for example higher earnings among naturalized than non-naturalized immigrants, might stem from diverse effects. It is possible that immigrants who acquire citizenship 


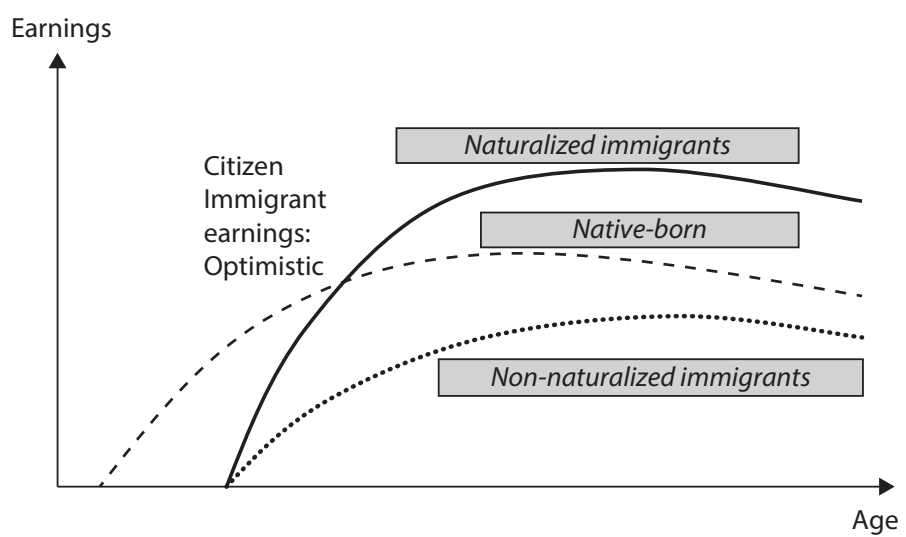

Figure 10.1 Age-Earnings Profiles Before and After Citizenship Ascension Source: DeVoretz and Pivnenko (2006) ${ }^{7}$

are just different from non-citizens (example.g., in their levels of education), and that these differences drive both ascension to citizenship and earnings, without any causal relationship between citizenship status itself and economic outcomes. Alternatively, the investment required to attain citizenship (e.g., acquisition of language skills), and the subsequent security or benefits that come with citizenship might lead to productivity and earnings gains for new citizens (technically, changing the earnings slope) or help them get better jobs (producing a bump in income after naturalization).

To better appreciate the main economic factors that yield citizenship ascension premiums, we provide a stylized version of this modern economic theory's outcomes. Figure 10.1 represents an age-earnings profile for immigrant citizens and non-citizens in their chosen host country.

In this two dimensional diagram, time (age) and earnings are the primary analytical variables, with citizenship ascension and earnings affected by age for any stylized immigrant contemplating citizenship ascension. There exist several possible combinations of age-earnings profiles to deduce the size of the citizenship economic premium. In Figure 10.1 we produce three different age earnings profiles for the host country native-born (dashed line), the host country immigrant population (dotted line), and finally their naturalized counterparts (solid line). Given these three profiles it is possible to produce two measures of the citizenship economic premium. The first measure of the citizenship premium would be the anticipated higher earnings of naturalized citizens relative to resident alien earnings. It is also

${ }^{7}$ Don DeVoretz and Sergy Pivnenko, 'The Economic Determinants and Consequences of Canadian Citizenship Ascension', in Pieter Bevelander and Don DeVoretz, eds., The Economic of Citizenship (Malmo: Malmo University, 2008). 
possible to measure the citizenship premium of naturalized citizens relative to the native-born. ${ }^{8}$

According to Figure 10.1, naturalized immigrants would earn more than both the native-born and their non-naturalized immigrant counterparts. However, empirical studies show significant variations in the effect of naturalization on immigrants' labour market outcomes among different national origins and across host countries.

Economists find that the rules governing how countries admit immigrants, and the rules governing naturalization are additional factors that affect the ultimate size of the economic premium gained from immigrants' naturalization. Too short a waiting period after immigration, for example, may inhibit the ability of a prospective citizen to gain enough human capital and labour force attachment to produce a substantial economic premium after naturalization. On the other hand, too long a waiting period may mean that candidates who have integrated into the labour market and gained valuable skills leave the country before they can become citizens.

The length of time before one can become a citizen is only one factor that shapes the economic premium from citizenship. Language requirements, for example, may help immigrants integrate into the country, but too strict a language provision might unduly restrict who attains citizenship (example.g., older candidates), diminishing any economic gains. Likewise the fact that many host countries do not allow naturalized citizens to keep dual nationalities reduces citizenship ascension rates and the aggregate economic premium.

For illustrative purposes, consider a theoretical country attempting to maximize both rates of naturalization and the economic benefit derived from them. Figure 10.2 depicts a hypothetical demand curve showing ascension rates-of the percentage of immigrants becoming citizens-and the citizenship premium-the economic bump that comes with naturalization.

With only a minimal waiting period, for example three years, the amount of immigrant accumulated country-specific human capital and the subsequent signal sent to employers is small. In this case, the short waiting period results in a small present value citizenship premium, in this hypothetical case only \$50. As the ascension waiting period grows to five years the present value of the derived citizenship premium increases to a maximum of $\$ 100$, as prospective citizens acquire more human capital which sends a stronger signal to employers who now pay more to these newly naturalized citizens.

Waiting periods greater than five years produce a gradual decline in the citizenship premium for two reasons. First, the payoff period shortens and thus there is less incentive to accumulate human capital while waiting to ascend to citizenship.

${ }^{8}$ Formally, these citizenship premiums are measured in terms of the differences in lifetime discounted incomes from age of citizenship ascension to retirement. In other words, $\mathrm{E}\left(\left(\mathrm{Y}_{\mathrm{ct}}-\mathrm{Y}_{\mathrm{ct}}\right)-\left(\mathrm{N}_{\mathrm{ct}}-\right.\right.$ $\mathrm{Nct})) /(1+\mathrm{t})$ where $\mathrm{t}=$ age of citizen or non-citizen. If this value is greater for a citizen than non-citizen it measures the discounted lifetime economic premium associated with citizenship ascension. 


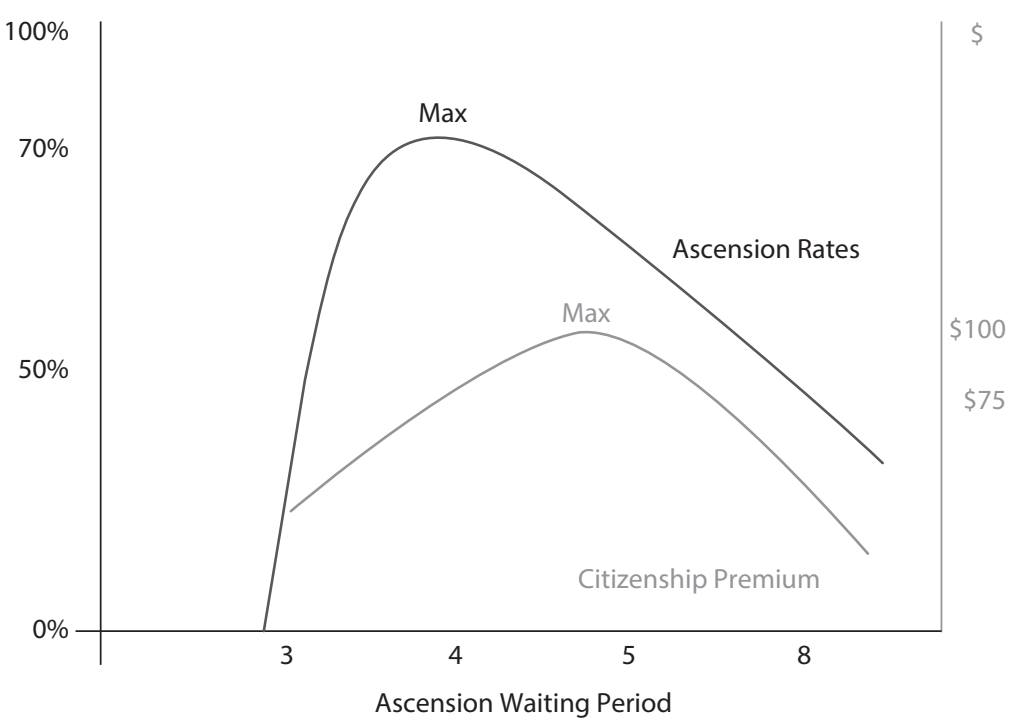

Figure 10.2 Ascension Rate and Economic Premium Trade Off Source: Bevelander and DeVoretz (2014) ${ }^{9}$

Next, a longer ascension waiting period produces some outmigration as the more economically capable candidates for citizenship leave the host country to seek a citizenship premium in their home or third country.

\section{Comparative Empirical Evidence From EURope AND North America under the Human Capital Model of Citizenship Ascension}

The acquisition of citizenship by immigrants has economic implications for three major parties: naturalized immigrants themselves, their countries of origin, and the host countries. These economic considerations may vary across countries of origin and destination but also depending on the human capital and socio-demographic

\footnotetext{
9 Pieter Bevelander and Don J. DeVoretz, The Economic Case for a Clear, Quick Pathway to Citizenship: Evidence from Europe and North America (Washington: Center for American Progress, 2014).
} 
characteristics of migrants such as their level of education or gender, and different combinations of the three parties involved.

\section{Naturalized Migrants}

In a now famous essay, Barry Chiswick claimed that there was no positive economic impact from citizenship accruing to naturalized immigrants in the US in the 1970 . $^{10}$ By the twenty-first century this conclusion was proved invalid in countries such as France, Germany, Sweden, Denmark, Norway, the US, and Canada. ${ }^{11}$ Yet the core of the controversy remains. While most scholars agree that naturalized immigrants perform better in the labour market than non-naturalized immigrants, there is a lack of consensus over the reasons for this gap.

They also found economic performance differences across naturalized citizens by countries of origin and their associated level of development, immigrants' entry path as well as gender. Women, humanitarian migrants, and those coming from less developed countries appear to benefit most from citizenship ascension in Canada, Denmark, France, Germany, Norway, Sweden, and the US. ${ }^{12}$

${ }^{10}$ Barry R. Chiswick, 'The Effect of Americanization on the Earnings of Foreign-Born Men', Journal of Political Economy 86, no. 5 (1978): pp. 897-921.

${ }^{11}$ Pieter Bevelander and Don DeVoretz, eds., The Economic of Citizenship (Malmo: Malmo University, 2008); Pieter Bevelander and Ravi Pendakur, 'Citizenship, Co-Ethnic Populations, and Employment Probabilities of Immigrants in Sweden', International Migration and Integration 13 (2012): pp. 203-222; Pieter Bevelander, Jonas Helgertz, Bernt Bratsberg, and Anna Tegunimataka, 'Who Becomes a Citizen, and What Happens Next? Naturalization in Denmark, Norway and Sweden', Delmi Report 6 (2015), online http://www.delmi.se/en/democracy\#!/en/who-becomes-a-citizen-and-whathappens-next; Bernt Bratsberg, James F. Ragan, and Zaffar M. Nasir, 'The Effect of Naturalization on Wage Growth: A Panel Study of Young Male Immigrants', Journal of Labor Economics 20, no. 3 (2002): pp. 568-597; Denis Fouge 're and Mirna Safi, 'Naturalization and Employment of Immigrants in France (1968-1999)', International Journal of Manpower 30, no. 1-2, (2009): pp. 83-96; Christina Gathmann and Nicolas Keller, 'Returns to Citizenship? Evidence from Germany's Recent Immigration Reforms', IZA discussion paper no. 8064 (2014), online http://ftp.iza.org/dp8064.pdf; Jonas Helgertz, Pieter Bevelander and Anna Tegunimataka, 'Naturalization and Earnings: A Denmark-Sweden Comparison', European Journal of Population 30, no. 3 (2014): pp. 337-359; Manuel Pastor and Justin Scoggins, 'Citizen Gain. The Economic Benefits of Naturalization for Immigrants and the Economy' (Center for the Study of Immigrant Integration, 2012), online http://dornsife.usc.edu/assets/sites/731/docs/citizen_ gain_web.pdf; Ravi Pendakur and Pieter Bevelander, 'Citizenship, Enclaves and Earnings: Comparing Two Cool Countries', Citizenship Studies 18, no. 3-4 (2014): pp. 384-407; Heidi Shierholz, 'The Effects of Citizenship on Family Income and Poverty', EPI briefing paper no. 256 (2010), online http://www. epi.org/files/page/-/bp256/bp256.pdf; Max Steinhardt, 'Does Citizenship Matter? The Economic Impact of Naturalizations in Germany', Labour Economics 19, no. 6 (2012): pp. 813-823; Madeleine Sumption and Sarah Flamm, 'The Economic Value of Citizenship for Immigrants in the United States' (Washington: Migration Policy Institute, 2012), online file://C:/Users/Matthew/Downloads/ citizenship-premium.pdf.

12 Ather H. Akbari, 'Immigrant Naturalization and its Impacts on Immigrant Labour Market Performance and Treasury', in Pieter Bevelander and Don DeVoretz, eds., The Economic of Citizenship 
In interpreting these findings, researchers debate whether there is a self-selection bias among naturalized immigrants or not. In other words, do immigrants who plan to acquire a new citizenship have or equip themselves with human capital and other social skills prior to citizenship ascension, which in turn allows them to enjoy the observed citizenship premium? Furthermore, do all immigrants who ascend to citizenship experience an economic premium or is this observed economic gain reserved for a select group of immigrants who arrive with premium social and human capital endowments? And, finally, do country-level immigration policies targeted to selecting immigrants influence the potential citizenship premium for their immigrants?

Bevelander and DeVoretz address these questions for five European and North American countries with different immigrant selection and citizenship-granting procedures-namely, Sweden, Norway, the Netherlands, the US, and Canada. ${ }^{13}$ This comparative analysis leads to the conclusion that the design of a country's immigration and citizenship policies influences the degree of economic integration of its potential citizens and, as a result, also the size of the economic premium derived from citizenship.

Three specific ascension rules are cited as the main policy factors affecting the size of the citizenship premium: the length of the waiting period, language requirements, and the absence of dual citizenship. A short waiting period may inhibit the ability of the citizenship candidate to acquire enough human capital to produce a substantial economic premium after naturalization, but the opposite can act perversely as immigrant candidates with a large amount of human capital may leave the host country before the waiting period has expired. Language requirements may also have differing effects: greater required language facility may increase immigrants' economic premium, whereas a more rigorous language requirement can discourage potential candidates to apply and encourage them to leave the host country for another country with lower or no language requirements. Finally, the literature is not conclusive on the correlation between dual citizenship policies by immigrant sending and host countries, and naturalization rates: while some studies show that the absence of dual citizenship provisions in either the host country or the immigrant's sending country would reduce citizenship ascension rates (see, example.g., Peters et al. 2016 or Vink et al. 2013) - which would ultimately also decrease the size of the economic premium derived from naturalization-others conclude the opposite (e.g., Helgertz and Bevelander 2016). ${ }^{14}$

(Malmo: Malmo University, 2008); Pendakur and Bevelander (n 11); Bevelander et al. (n 11); Fouge're and Safi (n 11); Gathmann and Keller (n 11); John E. Hayfron, 'The Economics of Norwegian Citizenship', in Pieter Bevelander and Don DeVoretz, eds., The Economic of Citizenship (Malmo: Malmo University, 2008); Pastor and Scoggins (n 11); Shierholz (n 11); Sumption and Flamm (n 11).

13 Bevelander and DeVoretz (n 11).

${ }^{14}$ Jonas Helgertz and Pieter Bevelander, 'The Influence of Partner Choice and Country of Origin Characteristics on the Naturalization of Immigrants in Sweden: A Longitudinal Analysis', International Migration Review, early view (2016), online http://dx.doi.org/10.1111/imre.12244; Floris Peters, Maarten 
One of the main hypotheses posed by Bevelander and DeVoretz states that potential immigrant citizens will get higher or lower economic benefits from naturalization depending on whether they have been through a double selection process or not. The first selection occurs when immigrants select themselves and make the decision to migrate. Receiving states with policies aiming to attract immigrants with specific profiles make the second selection. These policies are more common in North American and Australia than in Europe. A third selection happens when an immigrant decides to apply for citizenship acquisition and it is granted to him or her. Doubly selected immigrants should have higher human capital endowments, which will provide immigrants with more benefits from the process of naturalization.

Based on the results obtained in the case studies and depending on the benefits derived from naturalization for migrants, the above-cited countries can be classified in three categories: high (Canada), moderate (US), and low (Norway, Netherlands, and Sweden) citizenship premium countries. The economic premium was measured in terms of earnings or employment opportunities. This classification is also illustrative of country-level differences in immigration policies and, in particular, differences in their immigrant selection criteria.

For example, DeVoretz and Pivnenko reported significantly positive earning effects derived from naturalization in Canada. ${ }^{15}$ However, they conclude that a self-selection bias caused by a triple positive selection may have blurred their results, resulting from Canadian immigration policies, a significant presence of highly skilled immigrants, and immigrants' investments in human capital prior to naturalization.

Interesting results were reported by Akbari from the American case study: while immigrants from developing countries experienced a positive effect on earnings after naturalization, this effect was not as significant for immigrants from developed countries. ${ }^{16}$ Later studies confirm these findings. ${ }^{17}$

The Netherlands, Norway, and Sweden were included in the low economic premium group of countries as reported by Bevelander and DeVoretz. ${ }^{18}$ After controlling for human capital and sociodemographic factors, no citizenship premium was found for immigrants to these countries, with the exception of refugees to Norway. ${ }^{19}$

Vink, and Hans Schmeets, 'The Ecology of Immigrant Naturalisation: A Life Course Approach in the Context of Institutional Conditions', Journal of Ethnic and Migration Studies 42, no. 3 (2016): pp. 359381, online http://dx.doi.org/10.1080/1369183X.2015.1103173; Maarten Peter Vink, Tijana Prokic-Breuer, and Jaap Dronkers, 'Immigrant Naturalization in the Context of Institutional Diversity: Policy Matters, but to Whom?', International Migration 51, no. 5 (2013): pp. 1-20, doi:10.1111/imig.12106.

${ }_{15}$ DeVoretz and Pivnenko (n 7$)$.

16 Akbari (n 12).

17 Pastor and Scoggins (n 11); Shierholz (n 11); Sumption and Flamm (n 11).

${ }_{18}$ Bevelander and DeVoretz (n 11).

${ }^{19}$ Hayfron (n 12); Kirk Scott, 'The Economics of Citizenship: Is There a Naturalization Effect', in Pieter Bevelander and Don DeVoretz, eds., The Economic of Citizenship (Malmo: Malmo University, 2008); Pieter Bevelander and Justus Veenman, 'Naturalization and Socioeconomic Integration: The Case of the Netherlands', in Pieter Bevelander and Don DeVoretz, eds., The Economic of Citizenship (Malmo: Malmo University, 2008). 
In a later study, however, Bevelander and Pendakur ${ }^{20}$ found that citizenship acquisition has a positive impact on employment for a number of immigrant groups living in Sweden, notably, for non-EU/non-North American immigrants. Moreover, refugees-but not their family members-were reported to experience substantial gains from citizenship acquisition. These results were confirmed and extended by the same scholars in a study that compared the citizenship effect on the earnings of immigrants to Canada and Sweden. ${ }^{21}$ Finally, in a recent study by Bevelander et al., which compared the effect of naturalization on immigrants' employment and income outcomes in Denmark, Norway, and Sweden, a positive correlation was found between naturalization and a better economic performance among people from countries generally marked by having poor labour market integration. ${ }^{22}$ Only in a few cases, however, was this improved labour market outcome directly linked to the time of naturalization.

Studies conducted in France and Germany replicate most of these findings. Fougère and Safi (2009) found that acquiring French nationality has a significant positive relationship on naturalized immigrants' subsequent employability and that this is particularly true for groups who have a low probability of employment in the host country. Steinhardt ${ }^{23}$ documents strong self-selection within the immigrant workforce concerning naturalization in Germany. However, he still finds a wage premium earned by naturalized German immigrants, with a larger impact for nonEU immigrants. Gathmann and Keller (2014) ask whether a more liberal access to citizenship, resulting from two major citizenship ascension reforms in Germany, improved the economic integration of immigrants. ${ }^{24}$ Their estimates show a positive correlation between naturalization and labour market performance, with the returns of citizenship being more substantial for women and recent immigrants than for men and traditional guest workers. The authors conclude that while the liberalization of citizenship provides some benefits in the labour market, it is unlikely to result in full economic and social integration of immigrants to Germany.

In sum, these studies provide similar conclusions. Naturalized immigrants have higher human capital endowments than their counterparts and this explains their higher employment rates and income. Yet even after controlling for human capital and socio-demographic factors, there exists a separate citizenship effect for naturalized immigrants' labour market incomes in the majority of country case studies reported. This effect seems to be larger for immigrants from low-income countries, refugees and for women, and for immigrants naturalized in countries where they

${ }^{20}$ Pieter Bevelander and Ravi Pendakur, 'Citizenship, Co-Ethnic Populations, and Employment Probabilities of Immigrants in Sweden', International Migration and Integration 13 (2012): pp. 203-222.

${ }^{21}$ Pendakur and Bevelander (n 11). $\quad{ }^{22}$ Bevelander et al. (n 11).

${ }^{23}$ Steinhardt (n 11).

${ }^{24}$ Between 1991 and 1999, adolescents could obtain citizenship after eight years of residency in Germany, while adults faced a fifteen-year residency requirement. Since 2000, all immigrants face an eight-year residency requirement. 
are doubly selected. However, due to the possible existence of endogeneity between naturalization and greater human capital acquisition, it is difficult to establish causality. For example, Sumption and Flamm note that despite the potential economic and other benefits of citizenship, far fewer immigrants naturalize than are eligible to do so. ${ }^{25}$ They report that immigrants are more likely to naturalize if they have high levels of education, speak English well, and have been in the US for a long time. Moreover, due to data limitations, the reported studies were unable to control for unobservable characteristics that affect both citizenship and economic progress such as inherent skills, perseverance, or personal connections. Thus, we claim that qualitative studies are needed to control for the role of current unobservable characteristics and economic outcomes of naturalized immigrants.

The studies cited above focus on the potential economic premium earned by naturalized immigrants through the improvement of their labour market performance. However, naturalized immigrants may also benefit from public services provided to citizens but not to permanent residents in certain countries.

There are also some costs related to the naturalization process itself that migrants need to take into account when making the decision to apply. In chronological order, and depending on the migrants' knowledge of the host country language and other country-specific human capital attributes and administrative matters such as the validation of foreign degrees, the first step for prospective citizens is further investment in language courses and other courses to raise their professional standards or to help them pass often rigorous host country credential exams. Second, they may have to pay application fees that range from zero euros in France to 1,005 GB pounds in the United Kingdom. Finally, whereas in some countries becoming a citizen may have tax benefits, in others, naturalization may carry negative tax implications. In the US, citizens, but not permanent residents, are taxed on their worldwide income.

Among the direct and indirect costs associated with ascending to citizenship, Bevelander and DeVoretz highlight the absence of dual citizenship provisions in the host or sending country and the potential lost productivity and income absorbed by the immigrant during the waiting period before citizenship ascension. ${ }^{26}$ Recent research shows that migration flows are more intense among origin and destination countries that allow dual citizenship. ${ }^{27}$ Loss of citizenship in the sending country when either or both countries deny 'dual citizenship' is a large opportunity cost for some citizenship candidates who intend to return home to either work or retire. According to these authors, the loss of home country citizenship implies limited access to their home country's labour market; a potential loss of the right to hold

\footnotetext{
25 Sumption and Flamm (n 11). $\quad{ }^{26}$ Bevelander and DeVoretz (n 11).

${ }^{27}$ Hannah M. Alarian and Sara Wallace Goodman, 'Dual Citizenship Allowance and Migration Flow: An Origin Story', Comparative Political Studies, early view (7 February 2016), doi:10.1177/ 0010414015626443 .
} 
land, or the requirement to pay higher land taxes; the loss of entitlement to home country public services, such as subsidized education for their children; and the loss of entitlement to participate in the political process in the source country.

\section{Countries of Naturalization}

Most existing studies examine the effects of citizenship acquisition on immigrants' labour market performance; we have only found two studies that address the association between naturalization and host country's economy over all, and none that link naturalization and the sending country's economy. One way to think about the effects on countries is to consider tax benefits for host countries. Naturalization countries may also benefit from immigrants' citizenship acquisition if the labour market performance improves resulting in (i) higher income taxes receipts or (ii) greater economic contributions of naturalized immigrants versus permanent residents to the host country's economy.

According to Bevelander and DeVoretz, as immigrants' salaries and lifetime earnings increase as a result of naturalization, naturalized immigrants' federal and local treasury contributions also do. ${ }^{28}$ They add that these treasury contributions, in turn, yield benefits to non-immigrant residents in most host countries. Beyond economic benefits, host countries may also benefit from immigrants' citizenship acquisition when this increases immigrants' sense of belonging to the country of naturalization and in turn, has a positive effect on local peoples' attitude towards naturalized immigrants and therefore, increases social cohesion.

Pastor and Scoggins also asked about the economic impact on the overall host country's economy, from the hypothetical naturalization of immigrants who were eligible to do so in the US. ${ }^{29}$ In other words, they estimate the opportunity cost of having a low level of naturalization in the US. By using the mid-point between lower-bound and upper-bound estimates of gains and by setting a goal of shrinking the number of the eligible non-naturalized by half over five years, they estimated an earnings' boost of nearly 40 billion dollars to the US economy over the next decade. They also concluded that the impact on GDP can be even larger once the secondary effects of higher incomes on spending and demand are taken into account.

The last question asked by these scholars, based on their results, is why immigrants and policy makers do not pursue this citizenship premium. They respond that low host country language proficiency, a lack of knowledge about the application process, and the relatively high application fees discourage immigrants from applying for citizenship. These ideas coincide with Sumption and Flamm's conclusions. ${ }^{30}$ Pastor and

\footnotetext{
${ }^{28}$ Bevelander and DeVoretz (n 11).

30 Sumption and Flamm (n 11).

29 Pastor and Scoggins (n 11).
} 
Scoggins also claim that the US government could help by streamlining the process and considering reductions in application fees and other indirect costs. ${ }^{31}$

From the receiving state's perspective, naturalization costs involve a one-time expense in processing the potential naturalized citizen for security clearance as well as administering the citizenship examination and validating other papers such as country of origin and entry date into the host country. ${ }^{32}$ The host country's government will also have more citizens to protect and provide services for, such as in emergencies caused by natural disasters abroad. On a more symbolic level, these now naturalized outsiders may challenge the limits of the 'imagined' contours of the national political community.

Some other negative economic effects, at the country level, are more subtle and require a more detailed discussion. For example, what if immigrant ascension to citizenship results in return migration? The literature shows different behaviour for immigrants from different origin countries and human capital endowments. For example, while naturalized non-Turkish immigrants were found to be less likely to leave Germany, citizenship is not significantly correlated with the return migration of Turkish immigrants living in the same country. ${ }^{33} \mathrm{~A}$ more general study of the outmigration of the foreign-born conducted in the US reports substantial variation in outmigration rates across national origin groups and indicates that immigrants tend to return to wealthy countries not far from the US. Furthermore, according to the same study, if the immigrant flow is positively selected-in other words, if immigrants have above-average skills-the return migrants will be the least skilled immigrants; whereas if the immigrant flow is negatively selected, the return migrants will be the most skilled. ${ }^{34}$

The return migration of naturalized immigrants may have significant economic implications for countries of destination, especially in the case of highly skilled immigrants with higher contributions to the treasury. Dual citizenship allows immigrants who ascend to host country citizenship to enjoy social and economic benefits in both their countries of naturalization and origin. Substantial return migration to the sending country immediately after citizenship ascension implies potentially substantial post-retirement liabilities to the host country. This outcome arises if naturalized citizens leave their host country soon after citizenship ascension then proceed to work outside the host country for their labour market years

31 Pastor and Scoggins (n 11).

${ }^{32}$ Note that these costs may vary depending on the country of naturalization and that, more importantly, will not always be assumed by the host country (this is, example.g., the case of France) but they may also be fully or partially paid by the applicant immigrant (like in the UK, US, or Netherlands).

33 Torben Kuhlenkasper and Max Friedrich Steinhardt, 'Who Leaves and When?-Selective Outmigration of Immigrants from Germany', HWWI research paper no. 123 (2012), online http://www. hwwi.org/uploads/tx_wilpubdb/HWWI-Research-Paper-128.pdf.

${ }^{34}$ George J. Borjas and Bernt Bratsberg, 'Who Leaves? The Outmigration of the Foreign-Born', The Review of Economics and Statistics 78, no. 1 (1996): pp. 165-176. 
and are not subject to host country income taxes and then return to the host country upon retirement.

Furthermore, citizenship ascension can be motivated by and produce third country effects. For example, in either North America under the NAFTA agreement or in the European Union, ascension to citizenship in a member country allows heretofore uni-state immigrants a legal opportunity to move from their original host country to a third country to exploit their economic and social skills.

An economist would never view these third party effects as sub-optimal since any migration that increases the productivity of international immigrants is a positive outcome. Witness the multitude of recent Chinese-born Canadians working successively in the US courtesy of now holding a Canadian passport. ${ }^{35}$ However, the immigrant host country may resent these induced third party movements, especially if a combination of immigrant host country citizenship acquisition yields a passport with greater mobility provisions and if the prior accumulation of subsidized human capital in the host country facilitated their third country movement. This third country presence of naturalized dual citizens implies the existence of an infinite chain of naturalized progeny of a dual citizen couple living abroad. Thus countries have limited the prospect of the progeny of dual citizens from gaining citizenship under the principle of jus sanguinis leaving these progeny stateless. ${ }^{36}$

These above examples of potential economic loss to the host country caused by the onward mobility of newly created dual citizens must be compared to the magnitude of economic gains derived when the recently naturalized remain economically active in their host country. A successful host country naturalization policy would maximize the net economic gains not only to recently naturalized immigrants but also to resident citizens in the host country.

\section{Countries of Origin}

An understudied aspect of the economic implications of immigrants' naturalization is the effect of host country naturalization on the immigrant sending countries' economies. Some of the benefits resulting from migrants' citizenship ascension-and the resulting better economic situation of these naturalized citizens - for their countries of origin could include higher remittances, investment in property or a business in the homeland, the building of a retirement house, donations to their origin communities, etc. However, the opposite is also possible: the act of ascending to citizenship could

\footnotetext{
35 Under the NAFTA agreement naturalized Canadians (or Americans) can work in the United States (or Canada) in sixty-seven professions without having to obtain a visa.

${ }^{36}$ For example Canada does not allow the progeny of naturalized Canadians born abroad to obtain Canadian citizenship. However, progeny of Canadian-born couples born abroad are considered Canadian citizens.
} 
be part of a settlement process in the host country, to which the new citizens may feel more committed. As migrants' attachment from the origin to the destination country shifts, the frequency of their contacts, visits, and investments in their country of origin may also decrease over time. These two possible scenarios are not only influenced by time elapsed since migration but also by other factors such as the civil status of migrants in both countries, whether they have children and where the children live, whether the parents are still alive and where they live. Migrant sending countries such as China, which do not recognize dual citizenship, often economically penalize their third country naturalized citizens, reducing their incentive to return. ${ }^{37}$ Other countries such as India, which also does not recognize dual citizenship, have flexible admission and residency policies for heretofore Indian citizens. ${ }^{38}$

From a wider view of migration, citizenship ascension, and world productivity, naturalization may, at the same time, benefit both sending and destination countries. Let's take for example the case of naturalized Gujarati immigrants to the US or Canada. The fact that India has instituted a modified form of dual citizenship recognition results in two citizenship ascension premiums. First, Gujarati immigrant entrepreneurs and engineers will ascend to US or Canadian citizenship faster and at a greater rate with the impending loss of Indian citizenship removed, which in turn lowers the cost of host country citizenship acquisition. Beyond this lower cost of host country immigrant citizenship ascension is the prospect of naturalized Indo-Canadians or Indo-Americans working and investing in India.

One of the major potential costs absorbed by sending countries-namely the loss of their citizens and, as a result, sometimes of their tax-payers-is linked to the non-recognition of dual citizenship by either sending or host countries. However, this is not a commonly found scenario because (i) most sending countries are lowincome countries that do recognize dual citizenship (with the important exception of China) and (ii) naturalization countries that in theory do not accept it, in practice do not tend to prosecute their dual citizens.

\section{Some Conclusions}

In this chapter we have reflected on the potential economic implications of citizenship acquisition using a human capital model for citizenship ascension for the three

\footnotetext{
${ }^{37}$ For example, working visas are required for working age dual citizens while the dependents of these dual citizens are charged substantial school fees.

${ }^{38}$ India allows a form of dual citizenship such that naturalized Indian citizens abroad can return to India to work. However, they cannot be politically active and run for office or vote in Indian elections.
} 
major parties affected: naturalized immigrants themselves, their countries of origin, and the countries of naturalization. We have claimed that earlier approaches, such as the economic theory of clubs, lack the complexity to fully address this topic. In an attempt to do so, this chapter further develops the human capital model and the analysis of net tax transfers between three groups: immigrants, naturalized citizens, and the native-born. In addition, the human capital model has been expanded to incorporate new analytical challenges including the effects derived from the presence of dual citizenship and free trade zones. The economic costs and benefits of citizenship acquisition are then discussed from the point of view of naturalized immigrants, and their sending and host countries. Finally, these ideas have been illustrated by empirical studies conducted in North America and Europe. These studies show that the costs and benefits of naturalization vary depending on immigrants' characteristics such as human capital and gender, the standard of living of origin countries, type of migration, and immigration and naturalization policies in host countries, among which the immigrant selection policies, the provision of dual citizenship, language requirements, and the waiting time for naturalization are some of the most relevant factors.

We have stated that the vast majority of the studies on immigrants' naturalization focus on the labour market impact of citizenship ascension for the naturalized immigrant and the host labour market, and the subsequent fiscal impacts derived from naturalization. In comparison, the effect of naturalization on sending economies has received little or no attention. Below we present a research agenda based on this and other gaps and limitations we found in our literature review. We claim that more comparative and qualitative research is needed to address these questions.

How could we work around the self-selection bias to assess the real citizenship effect? Since the prospect of reaping economic benefits from naturalization entices immigrants to accumulate human capital prior to naturalization, comparative studies must be conducted to detect the 'pure' economic effect owing to citizenship ascension. One test that could be conducted across countries is to detect the differential rates of citizenship ascension and the resulting income effects for immigrants who accumulate similar amounts of capital.

Further ideas to analyse the effect of naturalization on host country's economy. There are numerous secondary economic effects that can impact the economic outcomes of host country born citizens. These economy-wide impacts on unemployment, wage rates, or income distribution of the host country born citizens can be detected via counterfactual experiments. For example, what would happen if all undocumented US residents gained citizenship? Would the effects differ if different groups, such as those under age thirty, or skilled workers, or the full-time employed, were granted citizenship rights? Obviously different counterfactual questions of a similar nature can be posed for other immigrant host countries.

How could we analyse the effect of naturalization on a sending country's economy? This is a difficult question to answer since few data sets exist to trace the origins and 
ultimate residency of host country naturalized citizens. For example, China does not recognize any naturalized Chinese born people who work or invest in China. These naturalized Chinese Canadians or Chinese Americans are recorded in China as Canadians or Americans working or living in China. Thus, small scale and specific studies must be conducted which can clearly identify the birthplace and ultimate citizenship of the return migrant. One area is promising, namely tracing the flows of naturalized citizens' human capital to their host countries. This has been done on a limited scale since the physical place of where the first and subsequent degrees are earned can identify the origin and host country of a returned naturalized citizen.

What factors condition a clear path to citizenship for individual host countries and specific groups of immigrants? Some countries have multiple paths to citizenship for different immigrant resident groups. A straightforward test would be to run controlled experiments across these multiple paths to observe possible differential rates of ascension and economic impacts owing to citizenship ascension.

Naturalization allows immigrants to not only enjoy formal rights and protections through the legal status of citizenship, but to become members of a national political community through citizenship status. It also allows naturalized migrants to have access to certain job opportunities restricted to host country citizens, freer movement between host country and third countries, accelerated rights to family unification, and so forth. On top of these rather obvious and measurable benefits of naturalization, citizenship acquisition may also be a 'natural' consequence of an immigrant's integration process and a shift in their sense of belonging from their country of origin towards their destination country. Therefore, we could state that naturalization does not always need to be a rational economic choice but it could also be an expression of more subjective identity and appreciation of legal and social institutions in the host country. Thus naturalization may still occur when there are no clear civic or economic benefits for the naturalized immigrant. However, the economic benefits derived from citizenship ascension can often be the force that entices the hesitant immigrant to become a citizen.

\section{BIBLIOGRAPHY}

Akbari, Ather H., 'Immigrant Naturalization and its Impacts on Immigrant Labour Market Performance and Treasury', in Pieter Bevelander and Don DeVoretz, eds., The Economic of Citizenship (Malmo: Malmo University, 2008).

Alarian, Hannah M. and Sara Wallace Goodman, 'Dual Citizenship Allowance and Migration Flow: An Origin Story', Comparative Political Studies, early view (7 February 2016), doi:10.1177/0010414015626443.

Becker, Gary, The Economics of Discrimination (Chicago: University of Chicago Press, 1973). 
Bevelander, Pieter and Don J. DeVoretz, The Economic Case for a Clear, Quick Pathway to Citizenship: Evidence from Europe and North America (Washington: Center for American Progress, 2014).

Bevelander, Pieter and Don DeVoretz, eds., The Economic of Citizenship (Malmo: Malmo University, 2008).

Bevelander, Pieter and Ravi Pendakur. 'Citizenship, Co-Ethnic Populations, and Employment Probabilities of Immigrants in Sweden', International Migration and Integration 13 (2012): pp. 203-222.

Bevelander, Pieter and Justus Veenman, 'Naturalization and Socioeconomic Integration: the Case of the Netherlands', in Pieter Bevelander and Don DeVoretz, eds., The Economic of Citizenship (Malmo: Malmo University, 2008).

Bevelander, Pieter, Jonas Helgertz, Bernt Bratsberg, and Anna Tegunimataka, 'Who Becomes a Citizen, and What Happens Next? Naturalization in Denmark, Norway and Sweden', Delmi Report 6 (2015), online https://www.google.se/url?sa=t\&rct=j\&q=\&esrc=s\&sou rce $=$ web\&cd $=2 \& v e d=$ oahUKEwituqKylcjNAhXLJSwKHaffCL4QFgghMAE\&url=http \%3A\%2F\%2Fwww.delmi.se\%2Fupl\%2Ffiles\%2F120588.pdf\&usg=AFQjCNHgk7Z9BRFHmGBoooEMqfIeYo6nw\&sig2=voACHUj7ilt_j48p7oGXNA.

Borjas, George J. and Bernt Bratsberg, 'Who Leaves? The Outmigration of the Foreign-Born', The Review of Economics and Statistics 78, no. 1 (1996): pp. 165-176.

Bratsberg, Bernt, James F. Ragan and Zaffar M. Nasir, 'The Effect of Naturalization on Wage Growth: A Panel Study of Young Male Immigrants', Journal of Labor Economics 20, no. 3 (2002): pp. 568-597.

Buchanan, James M., 'An Economic Theory of Clubs', Economica 32, no. 125 (1965): pp. 1-14. Chiswick, Barry R., 'The Effect of Americanization on the Earnings of Foreign-Born Men', Journal of Political Economy 86, no. 5 (1978): pp. 897-921.

DeVoretz, Don and Sergy Pivnenko, 'The Economic Determinants and Consequences of Canadian Citizenship Ascension', in Pieter Bevelander and Don DeVoretz, eds., The Economic of Citizenship (Malmo: Malmo University, 2008).

Fouge 're, Denis and Mirna Safi, 'Naturalization and Employment of Immigrants in France (1968-1999)', International Journal of Manpower 30, no. 1-2 (2009): pp. 83-96.

Frey, Bruno, 'Flexible Citizenship for a Global Society', Politics, Philosophy \& Economics 2, no. 1 (2003): pp. 93-114.

Gathmann, Christina and Nicolas Keller, 'Returns to Citizenship? Evidence from Germany's Recent Immigration Reforms', IZA discussion paper no. 8064 (2014), online http://ftp.iza. org/dp8o64.pdf.

Hayfron, John E., 'The Economics of Norwegian Citizenship', in Pieter Bevelander and Don DeVoretz, eds., The Economic of Citizenship (Malmo: Malmo University, 2008).

Helgertz, Jonas and Pieter Bevelander, 'The Influence of Partner Choice and Country of Origin Characteristics on the Naturalization of Immigrants in Sweden: A Longitudinal Analysis, International Migration Review, early view (2016), online http://dx.doi.org/ 10.1111/imre.12244

Helgertz, Jonas, Pieter Bevelander, and Anna Tegunimataka, 'Naturalization and Earnings: A Denmark-Sweden Comparison', European Journal of Population 30, no. 3 (2014): pp. 337-359.

Joppke, Christian, Citizenship and Immigration (Cambridge: Polity Press, 2010).

Kuhlenkasper, Torben and Max Friedrich Steinhardt, 'Who Leaves and When?-Selective Outmigration of Immigrants from Germany', HWWI research paper no. 123 (2012), online http://www.hwwi.org/uploads/tx_wilpubdb/HWWI-Research-Paper-128.pdf. 
Pastor, Manuel and Justin Scoggins, 'Citizen Gain. The Economic Benefits of Naturalization for Immigrants and the Economy' (Center for the Study of Immigrant Integration, 2012), online http://dornsife.usc.edu/assets/sites/731/docs/citizen_gain_web.pdf.

Pendakur, Ravi and Pieter Bevelander, 'Citizenship, Enclaves and Earnings: Comparing Two Cool Countries', Citizenship Studies 18, no. 3-4 (2014): pp. 384-407.

Peters, Floris, Maarten Vink, and Hans Schmeets, 'The Ecology of Immigrant Naturalisation: A Life Course Approach in the Context of Institutional Conditions', Journal of Ethnic and Migration Studies 42, no. 3 (2016): pp. 359-381, online http://dx.doi. org/10.1080/1369183X.2015.1103173.

Ruhs, Martin and Philip Martin, 'Numbers vs. Rights: Trade-Offs and Guest Worker Programs', The International Migration Review 42, no. 1 (2008): pp. 249-265.

Samuelson, Paul A., 'The Pure Theory of Public Expenditures', Review of Economics and Statistics 36, no. 4 (1954): pp. 387-389.

Scott, Kirk, 'The Economics of Citizenship: Is There a Naturalization Effect', in Pieter Bevelander and Don DeVoretz, eds., The Economic of Citizenship (Malmo: Malmo University, 2008).

Shierholz, Heidi, 'The Effects of Citizenship on Family Income and Poverty', EPI briefing paper no. 256 (2010), online http://www.epi.org/publication/bp256/.

Steinhardt, Max, 'Does Citizenship Matter? The Economic Impact of Naturalizations in Germany', Labour Economics 19, no. 6 (2012): pp. 813-823.

Sumption, Madeleine and Sarah Flamm, 'The Economic Value of Citizenship for Immigrants in the United States' (Washington: Migration Policy Institute, 2012), online http://www. migrationpolicy.org/research/economic-value-citizenship.

Tiebout, Charles M., 'A Pure Theory of Local Expenditures', Journal of Political Economy 64, no. 5 (1956): pp. 416-424.

Vink, Maarten Peter, Tijana Prokic-Breuer, and Jaap Dronkers, 'Immigrant Naturalization in the Context of Institutional Diversity: Policy Matters, but to Whom?', International Migration 51, no. 5 (2013): pp. 1-20, doi:10.1111/imig.12106. 